\title{
習慣性膝蓋骨脱臼の治療の小経験
}

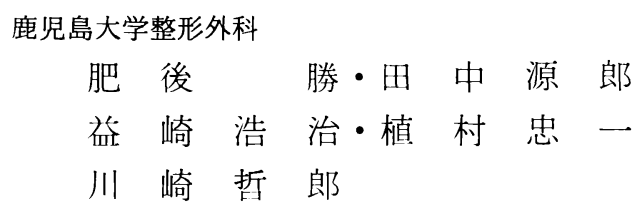

\section{Surgical treatment for the recurrent dislocation of the patella}

by

\author{
M. Higo, M. Tanaka, K. Masuzaki,
} T. Uemura and T. Kawasaki

Orthopedic Surgery, Faculty of Medicine Kagoshima University

\begin{abstract}
We reported 2 cases of the traumatic recurrent dislocation of the patella treated surgically. One patient was a 14 year old girl affected bilaterally, another was a 13 year old girl unilaterally. These knee joints had predisposing factors which were joint laxity, hypoplasia of the femoral lateral condyle, trachleal groove and quadriceps weakness. These patelle were dislocated laterally at the flexion of the knee joint. All dislocated patellae were treated by combined Campbell's and Roux-Goldthwait method. After 6 months, all knee joints had good mobility and no dislocation of the patella. But one patient complained of slight standing disturbance. Roentgenograms showed no findings of osteoarthrotic changes.
\end{abstract}

\section{緒言}

習慣性膝蓋骨脱臼は較的まれな疾患であり，その 発症には種々の因子が関与しているといわれ，そのた めに多種の手術的治療法が試みられ報告されてきた. 今回われわれは思春期に発症した外傷性習慣性膝蓋骨 脱臼の 2 症例に対し, soft tissue correction を行 なったので報告する.

症例 1.13 才, 女性

主訴：両側膝関節の伸展障害

家族歴：両親と妹に generalised joint laxity 認めたが，習慣性腅蓋骨脱曰は認めなかった。

既往歴：特記すべきことはない。

現病歴：昭和 52 年 12 月, 学校で起立していた時, 友人に後方より左膝窩部を強く蹴られた. その直後よ り左膝関節に激痛之腫脹が生じたが，某整骨師で湿布 を受け疼痛之腫脹は次第に軽減してきた. 昭和 53 年 2 月頃より左膝部の脱力感之起立困難に気付いたが,
徐々に症状の改善をみた. 昭和 53 年 5 月ソフトボー ルでボールを打つ瞬間右膝がガクッとなり立っておれ なくなった．その後，激痛之腫脹を生じた。昭和 53 年 7 月両側外傷性習慣性膝蓋骨脱臼の診断で当科に入 院した.

入院時所見：全身的には Carter and Wilkinson の定義する generalised joint laxity 該当する.

局所所見：左大腿の筋萎縮之筋力低下を認め，坐位 よりの起立はつかまり立ちであった．両側膝関節の腫 脹, 熱感, 圧痛等は認めず, 可動性も良好であった. 両側膝蓋骨は膝関節伸展位では正常の位置にある，し かし, 右膝蓋骨は膝の届曲につれ次第に外方に強く転 位し, 左膝蓋骨も膝の届曲につれ外方に脱臼する.

レ線検查：両側膝関節之も伸展位では特に異常所見 を認めない，軸写像で軽度の大腿骨外顆と顆間窩の形 成不全を認め, 膝蓋骨の形態は右側が Wiberg のIII 型, 左側がII 型であった（図 1).

治療は Campbell 法と Roux-Goldthwait 法を組 

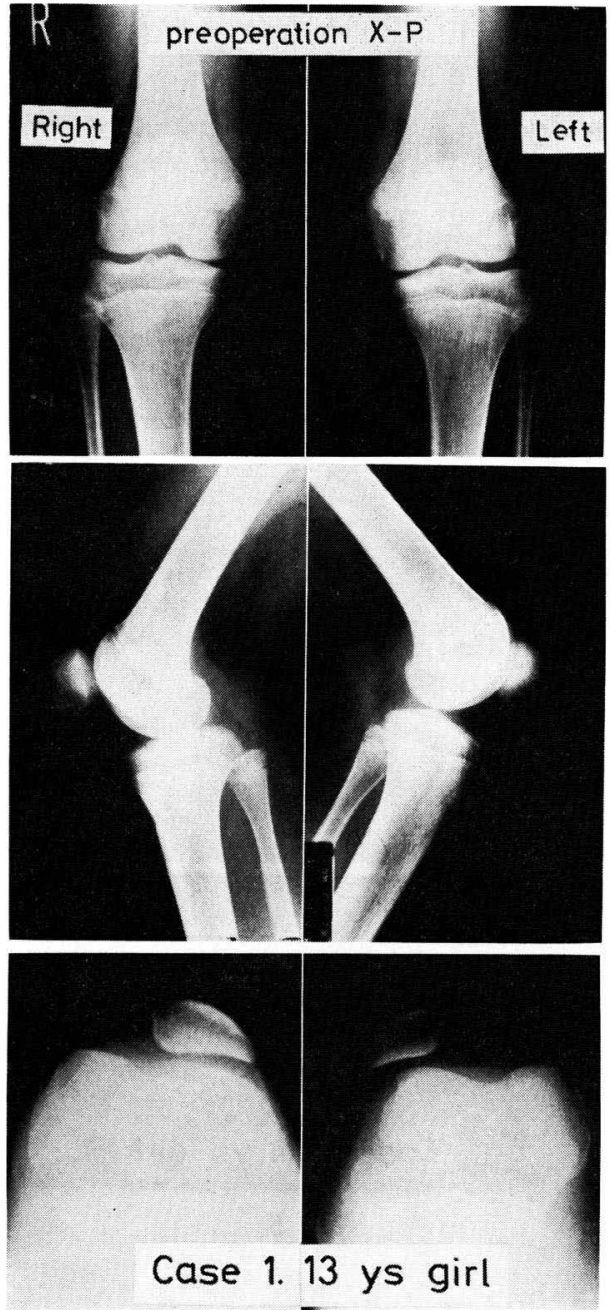

図 1

み合わせて行ない，先に脱臼の高度な左膝に，次いで 6 週後に右膝に対して手術を行なった。手技は膝蓋骨 内側縦切開にて侵入し，先に膝蓋骨外側支带，関節包 を切離した．次いで膝蓋骨内側に巾 $1.5 \mathrm{~cm}$ ，長さ 10 $\mathrm{cm}$ の筋膜弁を作製し，乙れを用いて大腿直筋を内側 に固定し，内側の欠損部を縫縮した（図 2 )。術中 関 節内を観察したが，両側膝蓋骨大腿骨関節軟骨面には 特に異常を認めなかった.

術後経過：術後約 3 週間ギプス固定を膝関節伸展位 にて行ない，以後後療法を行なった．術後約 6 週目に は両側膝関節の屈曲は約 140 度となり, 両側膝蓋骨の 脱臼も認めない. 術後 8 力月の調査時, 自覚的に疼痛

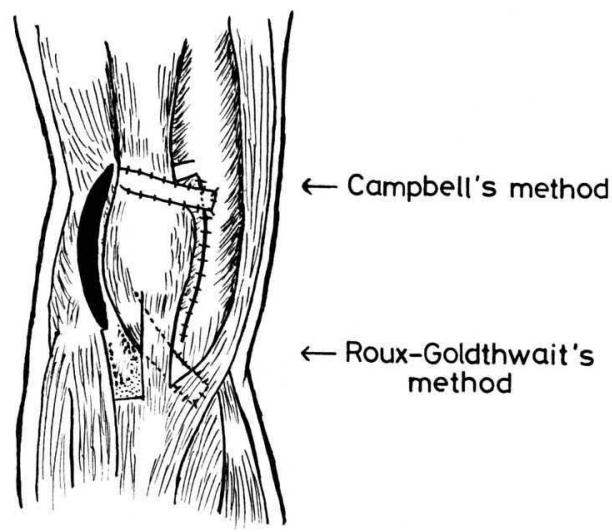

left knee

図2 于 術方法

なく, activity 屯術前より改善しているが，坐位よ りの起立がやや困難であった．他覚的には，両膝関節 とも炎症々状は認められず，㯟関節の可動性と膝蓋骨
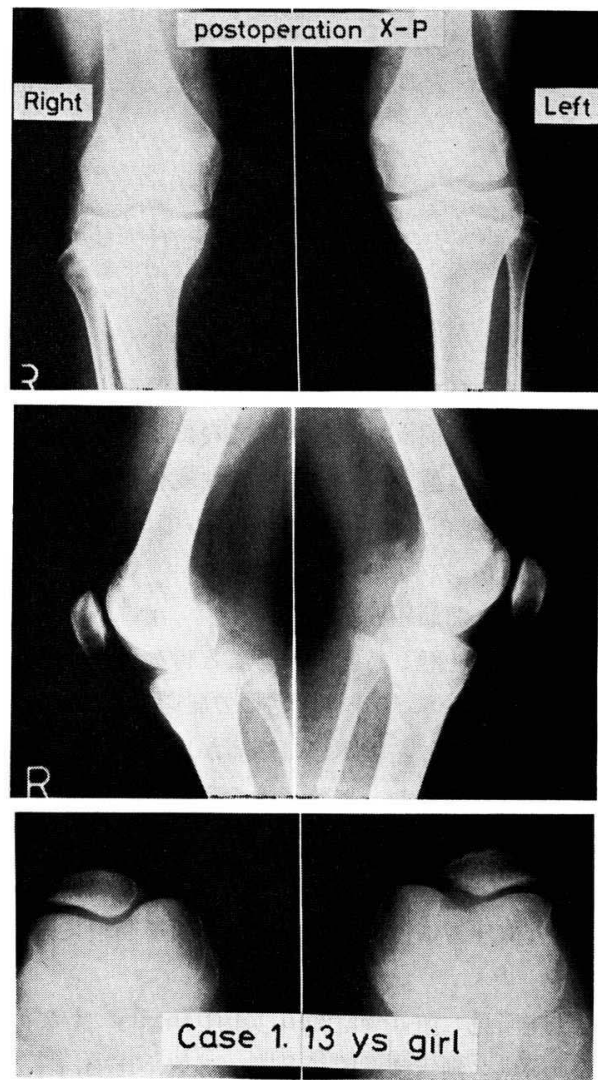

図 3 

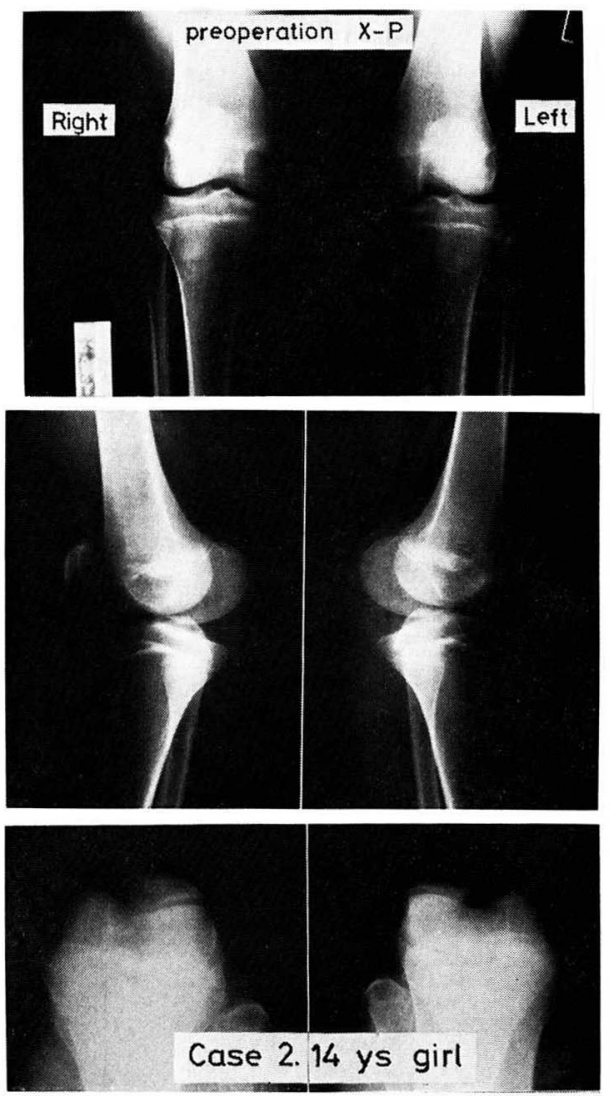

図 4

の安定性は良好であった．左大腿の筋萎縮之筋力低下 を認めたが，術前より改善されていた．調査時のレ線 検查では両側膝蓋骨の脱臼や変形性変化は認めなかっ た（図 3 ）. 現在迄良好な経過をとっている. 症例 2.14才, 女性

主訴：左滕関節屈曲時の疼痛

家族歴，既往歴：特記すべきととはない.

現病歴：昭和 52 年 8 月自宅にて兄弟達とふざけあ っていた時, 急に左膝関節の疼痛が出現し左膝関節の 届曲が不能となった. 左膝関節の腫脹, 熱感あり某医 で約 2 週間のギプス副子固定を受け軽快した. しか し，その後同様の症状が 3 回あった. 昭和 53 年 10 月, 左外傷性習慣性膝蓋骨脱臼の診断で当科に入院し た.

入院時所見: generalised joint laxity はない. 局所所見: 両側膝関節の腫脹, 熱感, 圧痛, 不安定 性なく, 可動性は良好であった. 左大腿部には筋萎縮
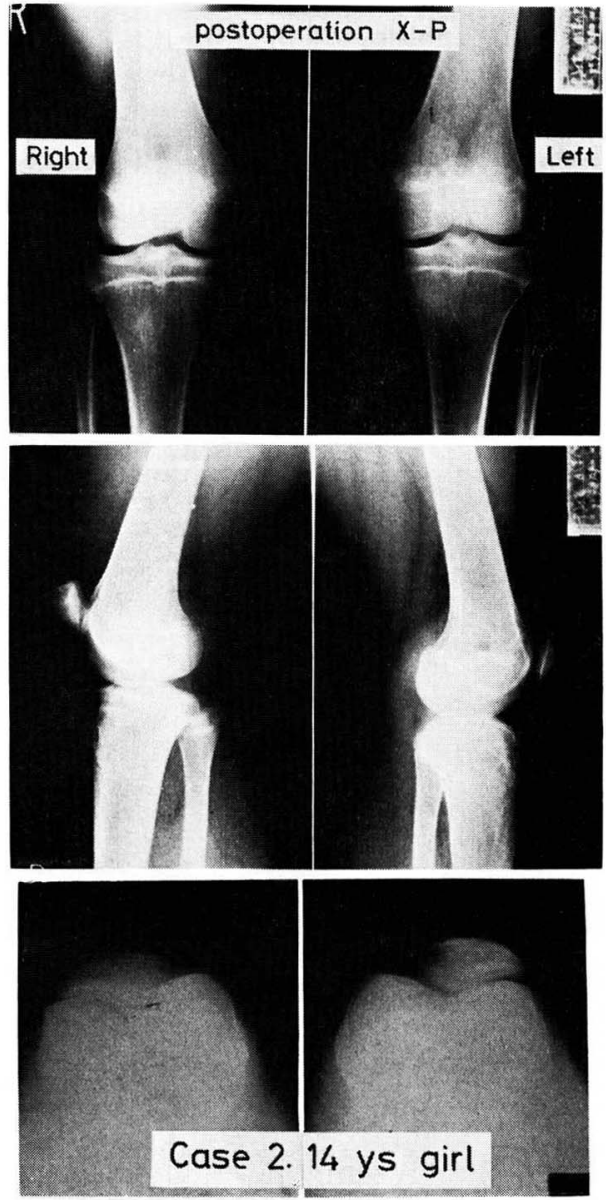

図 5

と筋力低下を認めた．左膝蓋骨は膝関節の屈曲につれ 外方に脱且する.

レ線検査：前後像では特に異常を認めず，立位伸展 位では軽度の反張膝を認める。軸写像では大腿骨外顆 と顆間窩の軽度形成不全を認め，左㯟蓋骨は外方に脱 臼している(図 4).

治療は症例 1 と同様に Campbell 法と RouxGoldthwait 法を組み合わせて行なった.

術後経過: 術後 2 週間膝関伸展位でギプス固定を行 なった. 次いで後療法を行なった. 膝蓋骨の脱臼は認 めなかった. 術後約 6 力月の調查時, 自覚的には坐位 よりの起立時にのみ左㯟部に軽度の疼痛があったが, activity は改善されていた. 他覚的に左膝関節には 腫脹，熱感，圧痛等はなく，可動性も良好であった。 
左大腿部に軽度の筋萎縮, 筋力低下を認めたが, これ らは術前より改善されていた. 調査時レ線検査では, 左㮏蓋骨の脱臼や変形性変化を認めなかった（図 5 ).

\section{考察}

われわれの 2 症例， 3 関節の膝蓋骨脱臼の脱臼形式 は， 2 関節が膝関節の屈曲につれ膝蓋骨は必ず外側に 脱曰し，1 関節は膝関節の届曲につれ外側に覀脱臼を おこす. われわれの 2 症例の膝関節には脱臼を生じゃ すい要因として, 大腿骨外顆, 顆間窩の形成不全, 大 腿四頭筋の筋力低下, joint laxity 等があり，これら に外傷が強く関与し発症したと思われる. その発症機 点について Jones は次のように述べている. 膝関節 周辺に脱臼を生じやすい素因を有している膝関節に外 傷が加わると, 膝蓋骨の脱臼が生じる.これにより, 膝蓋骨内側支帯や内側関節包の断裂や伸展がおき, 膝 蓋骨は正常の位置にとよ゙まりにくくなる. また同時に 内外側広筋の筋力の unbalance がおき, 膝蓋骨はよ り外側に引っ張られ，容易に脱臼するようになり再発 性脱臼となってくると述べている. 再発性脱臼の治療 の理念は, 脱臼の状態が長期にわたると関節軟骨が損 傷され変形性変化が生じるので, 早期に膝蓋骨を正常 の位置にもどす事により, patello-femoral joint に 生じる変形性変化を予防することにある. 膝蓋骨脱臼 の防止のためには早期に診断し, extensor mechanism の realignment を確立しなければならない. realignment 確立するための手術的方法としては, Hauser 法のような tibia tubercle transfer が主 としてなされてきた. しかし, Heywood, Harrison, Jones, Bowker, 片岡等は, 14 才前の骨成長期にあ る患者に Hauser 法を行なうと，骨端線障害による 反張膝等の骨成長障害を生じるので, 行なわない方が よいとのべている. Jones はこのような年令のもの には, soft tissue correction のみがなされるべき
手術法であると主張し, Campbell 法を勧めている. 最近 Hampson は Hauser 法では膝蓋骨の脱臼は予 防できるが, 変形性変化は予防できず, 長期 followup の結果は不良で, 16 年以上 follow-up した 20 例 中 18 例に変形性変化を認めたとのべている. Crosby は彼の平均 8.1 年 follow-up の手術治療例を $\mathrm{Hau}$ ser 法と soft tissue correction である Wagner 法にわけ，その結果を比較している. Hauser 法を行 なった 79 例中 $59 \%$ が satisfactory であり,その 20 \%に脱臼の再発をみ, また変形性変化も高率であった とのべ, Wagner 法を行なった 12 例では $75 \%$ が satisfactory であり, 変形性変化は 1 例も認めなか ったが， 3 例に脱臼が再発したとのべ，手術は soft tissue realignment を行なうべきであると述べてい る.このように Hauser 法は優れた方法とされてき たが, 最近再評価されているようである. 最近の文献 上の soft tissue correction の結果は, follow-up 期間はそれぞれ異なるが，表 1 のように良好と思われ る. われわれは患者の年令を考虑し, soft tissue correction によるより確実な extensor mechanism の realignment を確立するために Campbell 法と Roux-Goldthwait 法の組み合わせ法を行 なった. この組み合わせ法により, supratellar には 大腿直筋の内側固定, parapatellar には lateral release と内側の縫縮により, infrapatellar には外 側膝蓋靯帯の部分移行により, realignment をはか った. この方法の利点は Tate や Strong が述べて いるように，若年者に施行でき，骨成長障害をさけら れ，手技が容易で，早期に rehabilitation をはじめ られる点であろう. われわれの症例の予後について は, 将来変形性膝関節症へ発展する可能性は完全に否 定できないため, 十分な follow-up が必要であると 考えている.

表 1 Soft Tissue Correction

\begin{tabular}{|l|l|c|c|c|c|}
\hline & \multicolumn{1}{|c|}{ procedure } & $\begin{array}{c}\text { number } \\
\text { of } \\
\text { patient }\end{array}$ & $\begin{array}{c}\text { number } \\
\text { of } \\
\text { knees }\end{array}$ & satisfactory & unsatisfactory \\
\hline Tate (1973) & Campbell Roux-Goldthwait & 14 & 18 & $14(77 \%)$ & $4(33 \%)$ \\
Barrignton (1973) & Semitenodesis & $?$ & 35 & $33(94 \%)$ & $2(6 \%)$ \\
Strong (1974) & Campbell Goldthwait & 45 & 45 & $43(95 \%)$ & $2(5 \%)$ \\
Laing (1974) & Gracilis Transplantation & 31 & 37 & $29(78 \%)$ & $8(22 \%)$ \\
Crosby (1976) & Wagner & $?$ & 12 & $9(75 \%)$ & $3(25 \%)$ \\
\hline
\end{tabular}




\section{ま と め}

外傷性習慣性膝蓋骨脱臼の 2 症例に対 L, Campbell 法と Roux-Goldthwait 法の組み合わせ法を行 ない, 6〜8 カ月の follow-up の結果と若干の 文献 的考擦を加え報告した。

\section{文献}

1) Barrington, T.: J. Bone Joint Surg., 55B: 667, 1973.

2) Bowker, J. H. et al.: J. Bone Joint Surg., 46-A : 1451-1461, 1964.

3) Carter, C. and Wilkins, J.: J. Bone Joint Surg., 46-B: 40-45, 1964.

4) Crosby, E. B. et al.: J. Bone Joint Surg., 58-A : 9-13, 1976.

5) Hampson, W. G. J. et al.: J. Bone Joint Surg., 57-B: 209-213, 1975.

6) Harrison, M. H. M.: J. Bone Joint Surg., 37-B : 559-567, 1955.

7) Heywood, A. W.: J. Bone Joint Surg., 43B : 508-517, 1961.

8）片風 治：臨床整形外科, 3:347-356, 1968.

9) Laing, P. G.: J. Bone Joint Surg., 56-A :
1540, 1974.

10) Strong, T. E. : J. Bone Joint Surg., 56-A : 1304, 1974.

11) Tate, R. G. et al.: J. Bone Joint Surg., 55-B: 667, 1973.

発 言福岡整形外科病院 小林晶

九大で考案された semitendinosus stransfer に よる治療法について説明した. 最近恒久性脱臼にも行 なって今の所良い結果を得ている，御追試戴ければ幸 いである.

質問・発言鳥取大山上 剛

Semitendinosus の付着部を切離して Patella に 移行する方法で術後過矯性になる症例はないか. われ われは 1 例のみだが Semitendinosus を切離せずに Patella の内縁に移行する方法でよい成績を得てい 万.

回 答鹿児島大 肥後 勝 術中に膝蓋骨関節面に軟骨の変性は認められなかっ た。 